\title{
Analisa dan Perancangan Knowledge Management System pada SMA Negeri Ragunan Jakarta Selatan
}

\author{
Sita Anggraeni ${ }^{1 *}$, Sunarti ${ }^{2 * *}$, Jenie Sundari ${ }^{3 * * *}$ \\ * Teknik Informatika, STMIK Nusa Mandiri Jakarta,** Sistem Informasi,Universitas Bina Sarana Informatika \\ ***Teknik Informatika, STMIK Nusa Mandiri Jakarta \\ $\underline{\text { sita.sia@bsi.ac.id }}^{1}, \underline{\text { sunarti.sni@bsi.ac.id }}^{2}$, jenie.jni@bsi.ac.id ${ }^{3}$
}

\section{Article Info \\ Article history: \\ Received : 23-10-2018 \\ Revised : 27-11-2018 \\ Accepted : 05-12-2018}

Keyword:

Knowledge Management

System,

SMUN Ragunan,

Website,

Model Prototype,

Pelajar Olahragawan

\begin{abstract}
As one of the public high schools intended for student athletes and sportsmen in the Ragunan area of South Jakarta, Ragunan State Senior High Schools not only want to improve their students 'sports achievements but want to improve their students' academic performance. This research proposes to the need for a Knowledge Management System. The Knowledge Management concept tries to combine two major strengths namely Knowledge and Management by managing all the resources (resources) that are in the company so that it is easy to store, recover, and distributed to the right people quickly according to needs. By designing a web-based knowledge management system at Ragunan State High School, it becomes one of the learning media and information related specifically between teachers and students. The website is one of the media in many ways in delivering information, through education websites, the teachers and students can exchange information and even conduct learning activities. System development in this study using prototype methods, with this method of development and users can interact with each other during the system manufacturing process. This application can be applied to support the dissemination of information and dissemination of the existence of schools and to make effective the implementation of educational activities between teachers and students even without face to face.
\end{abstract}

\section{Pendahuluan}

Pendahuluan Sekolah merupakan suatu lembaga pendidikan tempat berlangsungnya proses pendidikan dan proses mengajar. Kegiatan operasional sekolah baik guru maupun murid sangat tergantung kepada penyebaran, pengelolaan, pengumpulan informasi serta pengorganisasian pengetahuan yang baik. Pembuatan bahan ajar, rencana pelaksanaan pembelajaran dan proses evaluasi hasil belajar merupakan pengetahuan yang kritikal di sekolah. Dalam Suprapto [1] menurut Debowski (2006) knowledge management adalah proses mengidentifikasikan, mendapatkan, mengorganisasikan dan menyebarkan asset intelektual yang penting bagi performa jangka panjang sebuah organisasi.
Perkembangan ilmu pengetahuan dan teknologi membawa pengaruh bagi dunia pendidikan. Untuk mewujudkan pendidikan berbasis Information Communication and Technology (ICT), diperlukan media pendukung agar dapat disejajarkan dengan organisasi lain yang juga menerapkan KMS (Knowledge Management System). Salah satu penerapan ICT adalah dibangunnya website sebagai sarana penyebarluasan informasi akademik dan kegiatan pendidikan lainnya [2].

Pada awal berdirinya SMA Negeri Ragunan Jakarta terbentuk atas kerjasama Departemen Pendidikan dan Kebudayaan, Komite Nasional Olahraga Indonesia dan Pemerintah Daerah Khusus Ibukota Jakarta. Namun, pada tanggal 24 Februari 1998 Penyelenggara Pemusatan Pendidikan dan Pelatihan Olahragawan Pelajar Nasional SMA Negeri Ragunan Jakarta menjadi tanggung jawab 
Menteri Pemuda dan Olahraga, Menteri Pendidikan dan Kebudayaan, KONI Pusat dan Gubernur DKI Jakarta.

Siswa-siswi di SMA Negeri Ragunan tidak hanya seorang pelajar, mereka berperan juga sebagai atlet olahragawan yang berprestasi secara nasional maupun internasional, namun Visi dan misi Sekolah ini mengutarakan tidak hanya prestasi olahraga saja menjadi keunggulan, namun peningkatan prestasi secara akademik dituntut sebagai bekal dalam persaingan global. Oleh karena itu diperlukan komunikasi dua arah (feedback) media interaktif antara Guru dan siswa serta budaya knowledge sharing sebagai media sosialisasi informasi antara Guru dan Bidang kurikulum ataupun Kepala Sekolah yang nantinya akan dituangkan dalam sebuah website Sistem Informasi Akademik yang nantinya akan membentuk Knowledge Management System dalam pengelolaan informasi yang dibutuhkan dan menunjang penyelenggaraan pendidikan untuk kemajuan Sekolah.

Konsep pada Knowledge Management mencoba menggabungkan dua kekuatan besar yaitu Knowledge dan Management dengan mengelola semua sumber daya (resource) yang ada dalam dalam perusahaan sehingga mudah dalam penyimpanan, diperoleh kembali, serta didistribusikan kepada orang yang tepat secara cepat sesuai kebutuhan. Sehingga diharapkan knowledge yang ada dalam perusahaan tidak tergantung pada manusia/pengguna user [3]. Manusia dalam konteks manajemen pengetahuan (knowledge management) adalah sumber pengetahuan, inovasi, dan pembauran [4]

Pada penulisan ilmiah studi kasus [5] menempatkan Knowledge Management sebagai sarana dalam mengatur, menyimpan dan memelihara knowledge dalam Yayasan Pendidikan oleh para staf pengajar maupun pegawai yang ada di sekolah, seperti penyampaian informasi yang berkaitan dengan akademik, bahan ajar, pembinaan atau perkembangan sekolah yang sering disampaikan secara lisan dan mengakibatkan salah pengertian dalam penyampaiannya ataupun salah pengertian karena tidak lengkapnya sebuah informasi.

Knowledge management yang efektif harus dimulai dengan melihat secara strategis mengenai pengetahuan apa yang diperlukan oleh organisasi [6] . Banyak organisasi menggunakan knowledge management sebagai sarana penunjang proses-proses pemberdayaan knowledge yang efektif yang melibatkan banyak elemen seperti manusia, budaya, proses kepemimpinan dan teknologi [7] . Konsep knowledge management dapat menjadi sebuah solusi untuk meningkatkan penguasaan pengetahuan dalam kegiatan penyajian dan penyimpanan data, informasi dan komunikasi di suatu instansi [8] seperti halnya pada SMA Negeri Ragunan dalam penelitian ini.

\section{TinjauAn PUStaka}

Dengan perancangan knowledge management system berbasis web pada SMA Negeri Ragunan menjadi salah satu media belajar serta informasi yang berkaitan khususnya antara guru dan siswa. Website merupakan salah satu media dari sekian banyak cara dalam penyampaian informasi, melalui website pendidikan maka para guru dan siswa dapat saling bertukar informasi bahkan melakukan kegiatan pembelajaran. Siklus peran website dalam knowledge management [9]:

1) Melalui media website para pengguna dapat bertukar pikiran, mensosialisasikan pengetahuan yang ada ataupun yang baru untuk dipergunakan kapanpun dan dimanapun tanpa harus tatap muka

2) Masing masing pelaku sistem dapat saling beinteraksi dalam suatu tujuan

3) Hasil dari kegiatan interaksi tersebut dapat membentuk pengetahuan baru dalam menghasilkan informasi (data yang diolah)

4) Website berfungsi sebagai aset informasi dalam sebuah media penyimpan berbagai pengetahuan yang akan siap di sharing

Dengan terbentuknya budaya berbagi informasi (knowledge sharing) akan meningkatkan bagi para pelaku sistem organisasi untuk menyumbangkan informasi yang dimilikinya sehingga sebuah website mampu memfasilitasi akses dalam penggunaan informasi yang tersimpan baik dalam suatu tujuan organisasi.

Pengembangan sistem dalam penelitian ini dengan menggunakan metode prototype, dengan metode ini pengembangan dan pengguna dapat saling berinteraksi selama proses pembuatan sistem [10]

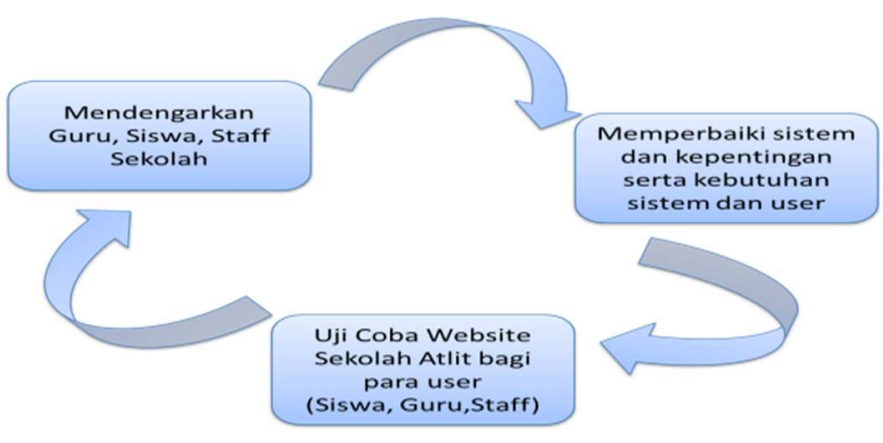

Gambar 1 Model Prototype SMAN Ragunan

Tahap-tahap pengembangan prototype model menurut Roger S Pressman Ph.D adalah:

1) Mendengarkan pelanggan atau pengguna

Pada tahap ini dilakukan pengumpulan kebutuhan dari sistem dengan cara mendengar keluhan pelanggan atau pengguna, jadi untuk membuat suatu sistem yang sesuai kebutuhan, maka harus diketahui terlebih dahulu bagaimana sistem yang sedang berjalan dan masalah yang terjadi

2) Merancang dan membuat prototype

Pada tahap ini dilakukan perancangan dan pembuatan prototype sistem yang dibuat sesuai dengan kebutuhan 
sistem yang telah didefinisikan oleh pelanggan atau pengguna

3) Uji Coba

Pada tahap ini prototype dari sistem diuji coba oleh pelanggan atau pengguna, kemudian dilakukan evaluasi kekurangan dari kebutuhan pelanggan atau pengguna. Pengembangan kemudian kembali mendengarkan keluhan dari pelanggan atau pengguna untuk memperbaiki prototype yang ada.

\section{Metode Penelitian}

Pada penelitian ada digunakan metode kualitatif dimana menekankan pada makna, penalaran dan definisi suatu situasi tertentu, lebih banyak meneliti hal-hal yang berhubungan dengan kegiatan operasional yang dilakukan sehari-hari . Perancangan dari hasil analisis ini adalah perancangan Sistem Informasi Akademik dengan berbasis Web untuk membangun knowledge management system, penelitian dilakukan melalui beberapa tahapan yang terstruktur dengan tujuan mendapatkan data yang tepat dan akurat melalui langkah-langkah kegiatan.

Tahapan Penelitian merupakan pengembangan dari konsep berfikir yang dijadikan acuan dalam mencari penyelesaian masalah yang ditemukan. Pengumpulan data didapatkan dari kepustakaan yang mengumpulkan beberapa literatur dari beberapa jurnal dan artikel ilmiah yang terkait dengan knowledge management system dan pengumpulan informasi yang efektif dan tepat juga dilakukan dengan beberapa metode diantaranya :

a. Observasi

Pada kegiatan ini dilakukan pengamatan langsung terhadap kegiatan dan proses knowledge sharing dalam kegiatan penyelenggaraan pendidikan pada SMA Negeri Ragunan, diantara siswa, Guru dan pihak lainnya yang saling terkait, hal ini bertujuan melihat kondisi dan mengamati bagaimana proses knowledge sharing berjalan.

b. Wawancara

Pada kegiatan ini dilakukan wawancara kepada beberapa Guru/Wali Kelas , Staff Kurikulum,staff IT serta Kepala Sekolah serta siswa SMA Negeri Ragunan, agar mendapatkan informasi dan penjelasan langsung dari pihak yang terkait (stakeholder) tentang bagaimana kegiatan dan proses knowledge sharing yang berjalan.

Dari hasil analisa ini maka akan diperoleh kebutuhan dari pengetahuan yang dibutuhkan oleh organisasi, maka dari komponen-komponen penyusun knowledge management, dibuatkan solusi dalam teknologi informasi yang berperan dalam memepermudah pengelolaan dan penyebaran pengetahuan didalam organisasi.

\section{Pembahasan}

Metode perancangan sistem dalam penelitian ini menggunakan UML (Unified Modelling Languange) yang terdiri dari use case diagram, class diagram, component diagram, deployment diagram.

\section{A. Use Case Diagram}

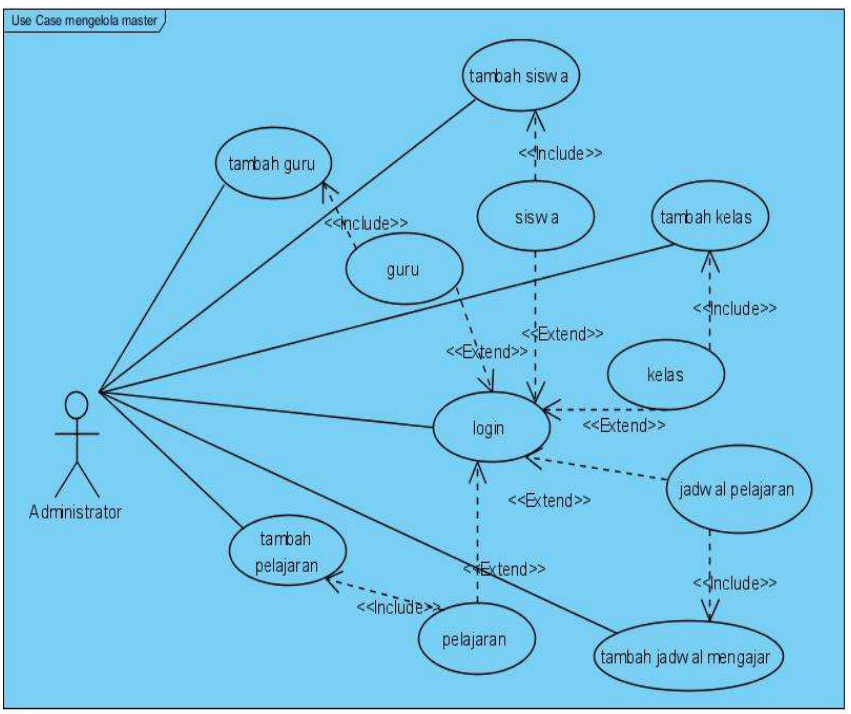

Gambar 2 Use Case Administrator

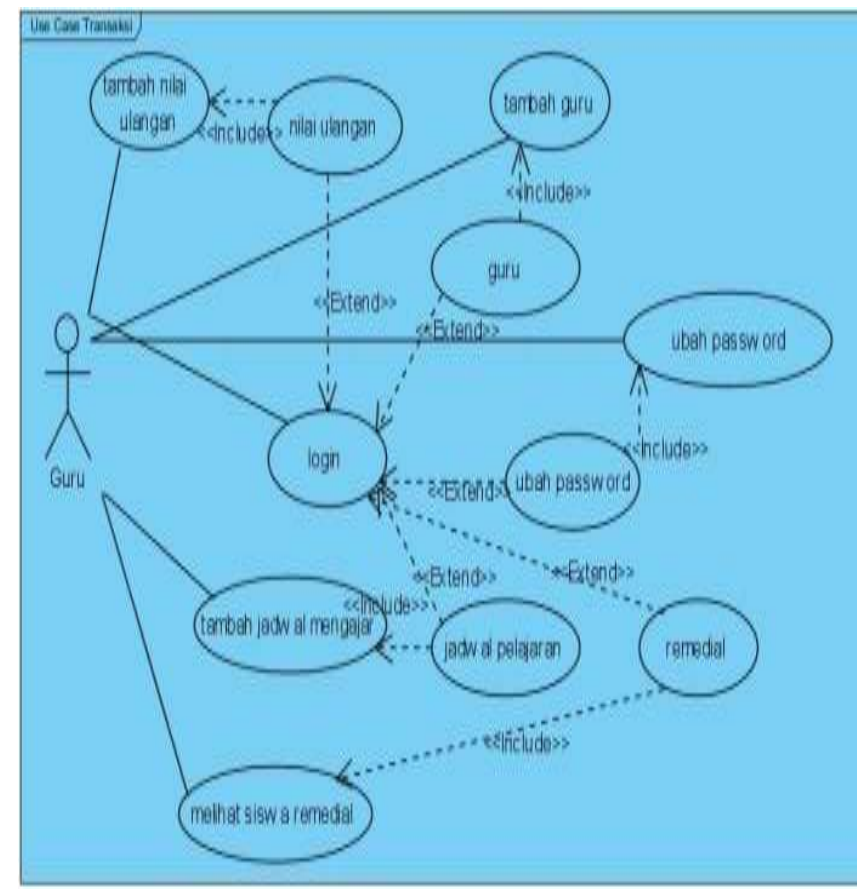

Gambar 3 Use Case Guru. 


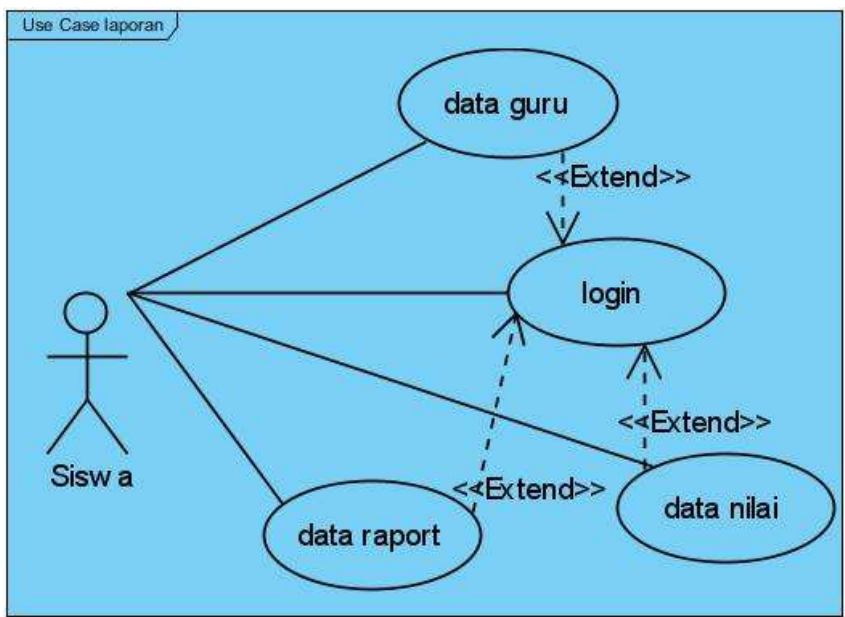

Gambar 4 Use Case Siswa

Use case diagram menggambarkan fungsionalitas yang diharapkan dari sebuah sistem Akademik SMA Negeri Ragunan. Use case diagram mempresentasikan actor yang terlibat dalam satu atau lebih proses dalam sistem. Gambar diatas terdiri atas Administrator, Guru dan siswa. Level wewenang akses pada tiga pengguna pada website ini adalah:

1) Administrator

Pada level ini user ini (staf IT) memiliki hak akses penuh dalam mengakses sistem website, sehingga diperlukan login untuk mengontrol menu-menu tertentu oleh user lainnya. Administrator bertanggung jawab penuh terhadap sistem seperti manajemen basis data seperti input data, menghapus dan mengedit data dari sistem akademik yang ada.

2) Guru

Pada level ini user ini memiliki hak akses dalam mengontrol nilai siswa dalam mengsharing informasi berupa nilai dan memberikan informasi atau perubahan jadwal mengajar dan memberikan kesempatan dalam informasi bagi siswa dalam hal remedial nilai dalam suatu pelajaran.

3) Siswa

Pada level ini user ini mendapatkan informasi akhir dalam melihat informasi nilai, dengan melakukan login dan memberikan kemudahan walaupun sedang melakukan pertandingan atau kompetisi olahraga di luar sekolah, sehingga terjadi feedback antara Guru dan siswa sehingga prestasi siswa bisa terkontrol secara akademik secara berkelanjutan.

\section{B. LRS (Logical Record Structure)}

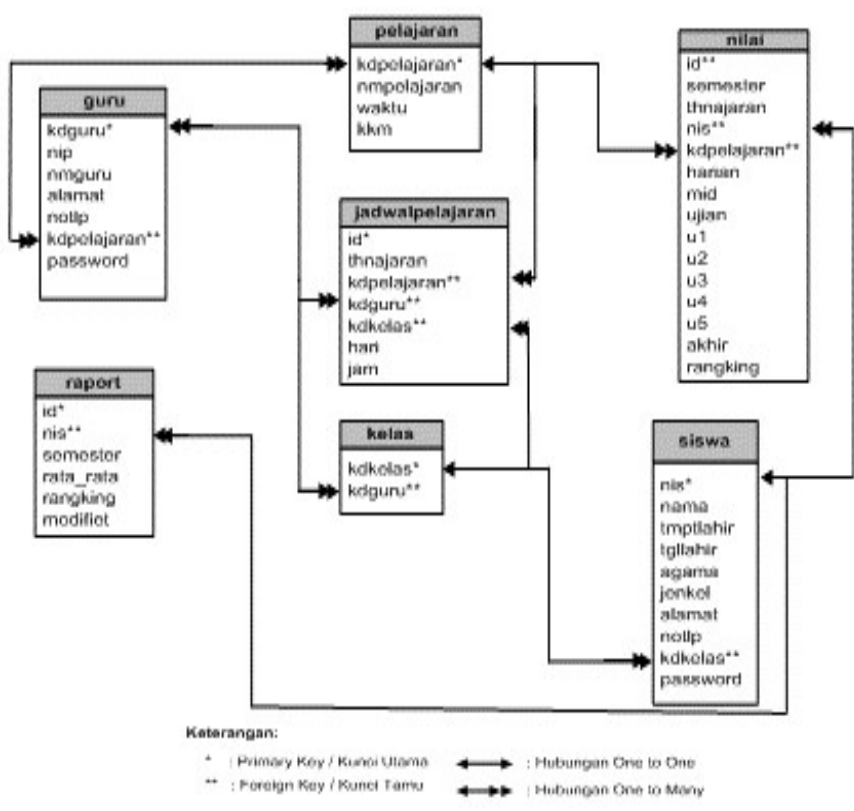

Gambar 5 Pembentukan Class Diagram

LRS (Logical Record Structure) ini mendeskripsikan objek-objek entitas yang akan membentuk sebuah Class diagram yang berisi atribut yang saling berelasi dari berbagai fungsi dalam suatu sistem yang akan dirancang berbasis website.

\section{Component Diagram}

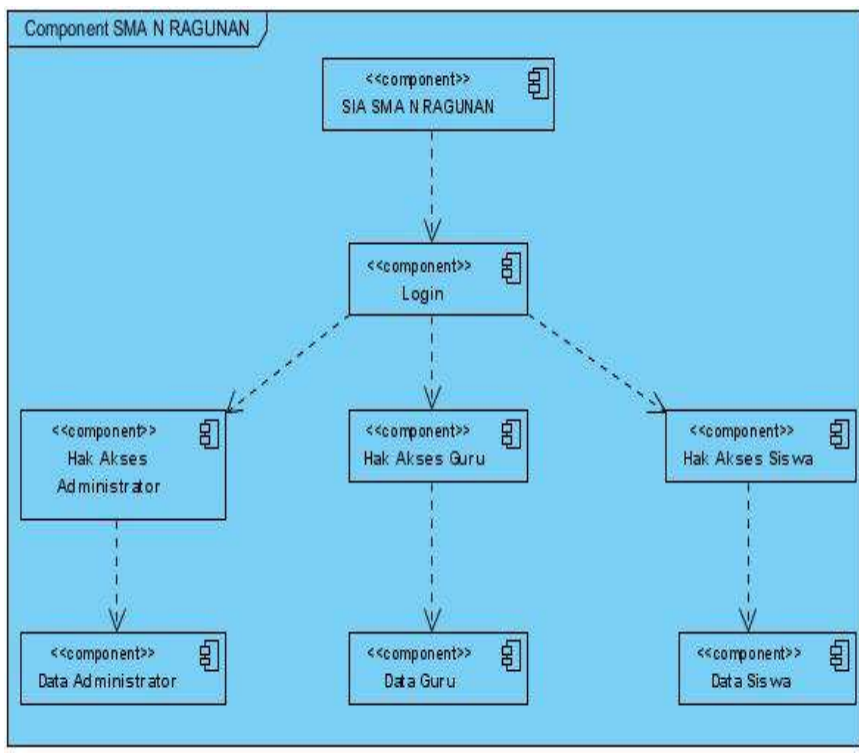

Gambar 6 Component Diagram

Component diagram pada sistem ini menunjukkan organisasi dan ketergantungan antar sekumpulan komponen yang akan dirancang berbasis website. 


\section{Deployment Diagram}

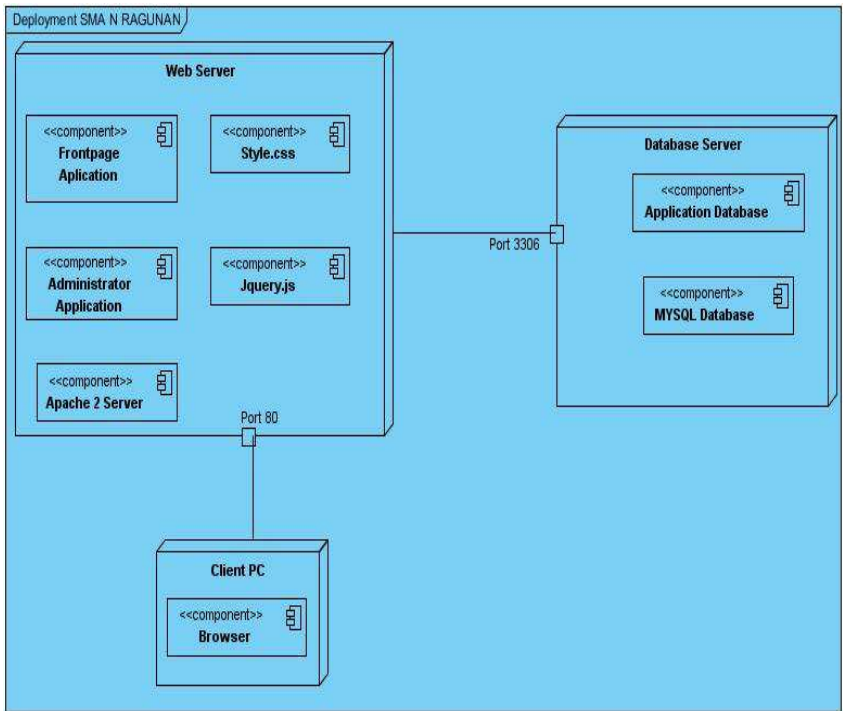

Gambar 7 Deployment Diagram

Deployment diagram pada sistem ini menunjukkan konfigurasi komponen yang terdiri dari node yang merupakan perangkat keras dan membungkus satu atau lebih komponen dalam proses eksekusi aplikasi yang akan dirancang berbasis website.

Pada desain web Knowledge Management System SMA Negeri Ragunan Jakarta, menu pada halaman website terdiri atas halaman utama, yang berisi sejarah (struktur organisasi) dan profile sekolah, galeri kegiatan sekolah dan menu saran kritik bila ingin memberikan dalam halaman guest ini semua tertampil secara umum dan dapat dilihat oleh siapa saja. Untuk Knowledge sharing antara Guru dan siswa maka akan tertampil beberapa menu Login dari tiga user yakni Administrator, Guru dan Siswa.

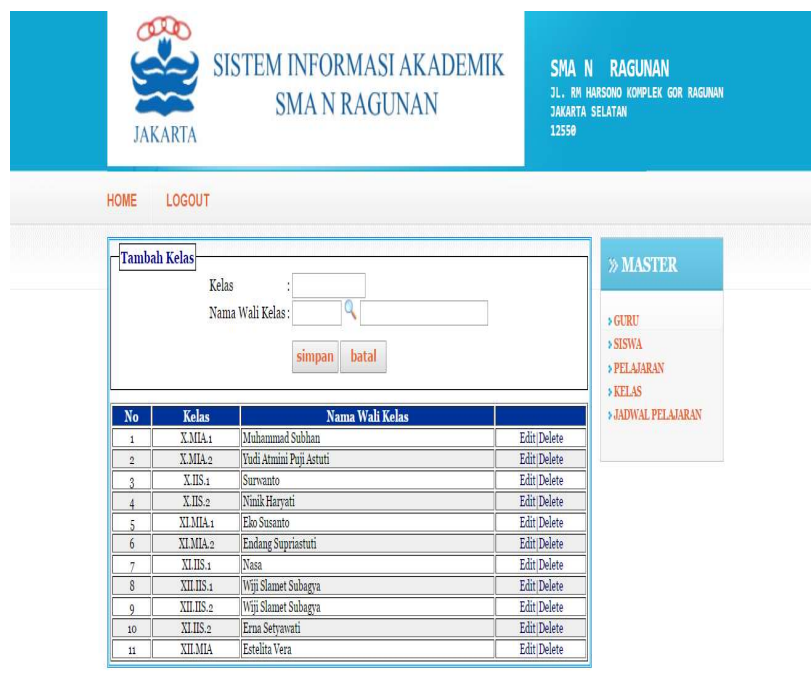

Gambar 8 Menu Dashboard Administrator
Setelah Admin melakukan login maka menu dashboard khusus akan tampil untuk memberikan hak akses penuh untuk administrator melakukan manajemen basis data website seperti penambahan, pengubahan data hingga penghapusan data pada sistem

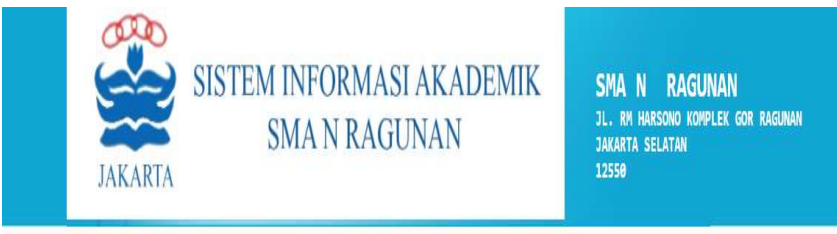

HOME LOGOUT

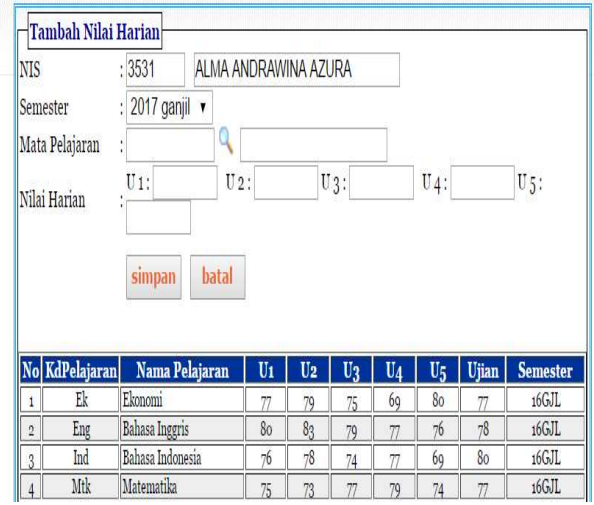

SAKADBMIIK

$\rightarrow$ MLLIHHRTIS

NLIILIAN

RENEDIL

JADWAL MEVIGUIAR

RAIGKNG

TRAHPASSIORD

Gambar 9 Menu Olah Nilai Oleh Guru

Setelah Guru melakukan login maka menu dashboard Guru akan berisi pengolahan nilai harian,ujian,remedial, pemberian ranking hingga informasi jadwal mengajar dan remedial bagi siswa.

\begin{tabular}{|c|c|c|c|c|c|c|c|}
\hline Aama & ACHMADYU & & Rela & & X.MA.1 & & \\
\hline $\mathrm{I}_{0}$ & Kode Pelajaran & Tama Pelajaran & Havian & IIII & TAS & KKII & Hasil \\
\hline I & Ek & Elonomi & 80 & 77 & 78 & 77 & 78.00 \\
\hline 2 & SnM & Seni Budaya & 88 & 79 & 87 & 78 & 84,00 \\
\hline 3 & Sio & Sosiologi & 76 & 80 & 80 & 75 & 79.20 \\
\hline t & Pkn & Pendididkan Kertaraganegeraran & 80 & 80 & 77 & 75 & 78.80 \\
\hline 5 & Pjo & 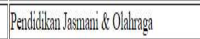 & 79 & 80 & 88 & 75 & 83.00 \\
\hline 6 & Kma & Kimia & 77 & 79 & 88 & 75 & 8220 \\
\hline 7 & Geon & Geognafif & 80 & 90 & 70 & 75 & 80.00 \\
\hline 8 & Fks & Firika & 80 & 70 & 79 & 75 & 73.60 \\
\hline 9 & हn! & badang ingyis & 80 & 90 & 10 & 70 & 80.00 \\
\hline 10 & mith & Matenatika & 78 & 80 & 77 & 75 & 784.40 \\
\hline 11 & ind & batams indonsesia & 88 & 70 & 80 & 75 & 77.60 \\
\hline 12 & Tili & 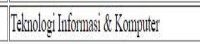 & 80 & 79 & 80 & 79 & 79.60 \\
\hline
\end{tabular}

Gambar 10 Menu View Nilai Oleh Siswa

Setelah Siswa melakukan login bisa mendapatkan beberapa informasi seperti jadwal data guru serta jadwal remedial perbaikan nilai, kemudian data nilai atau nilai remedial hingga pencetakan nilai serta mengetahui ranking. 
Setelah tahapan perancangan dan pembuatan aplikasi, maka pada tahap akhir dilakukan pengujian aplikasi untuk mengetahui aplikasi yang dibuat dapat berjalan dengan baik. Pengujian aplikasi dilakukan berdasarkan blackbox testing dari pilihan menu yang ada sesuai use case yang dibuat. Dari hasil pengujian ini, dilihat dari kegunaan menu-menu pada form yang ada pada website dalam pengolahan data dan penyebaran dan pengaturan informasi bagi Guru dan siswa serta administrator, sehingga pengujian ini sesuai harapan menjadi wadah knowledge management pada SMA Negeri Ragunan.

\section{KESIMPULAN}

Dari hasil pembahasan perancangan knowledge management system SMA Negeri Ragunan berbasis web menggunakan metode pengembangan model prototype dapat disimpulkan sebagai berikut.

1) Bahwa aplikasi ini dapat diterapkan guna mendukung penyebaran informasi dan sosialisasi keberadaan sekolah serta mengefektifkan penyelenggaraan kegiatan pendidikan antara guru dan siswa walaupun tanpa tatap muka, dikarenakan para siswa kerap kali mengikuti turnamen ataupun olimpiade olahraga diluar sekolah.

2) Fungsi-fungsi yang ada dapat menerapkan fungsi knowledge management berupa informasi, memudahkan siswa mengetahui nilai dan mencetaknya bahkan dapat mengetahui nilai perbaikan saat mengalami kegagalan dalam ujian, fungsi knowledge sharing berupa pemberitahuan jadwal guru untuk memberikan remedial memudahkan siswa dalam pencapaian nilai akademik yang maksimal.

3) Kedepannya seiring dengan kemajuan teknologi dan hausnya akan kebutuhan akan pengetahuan dan informasi dari sebuah sistem memungkinkan adanya pengembangan sistem selanjutnya yang berisi banyak fitur yang dibutuhkan oleh para penggunanya ataupun penambahan pengguna user lainnya sesuai kebutuhan.

\section{UCAPAN TERIMA KASIH}

Ucapan terima kasih ditujukan kepada Akademisi yang berada pada STMIK Nusa Mandiri Jakarta dan Universitas Bina Sarana Informatika atas dukungannya.

\section{DAFTAR PUSTAKA}

[1] C. A. Suprapto and S. Assegaff, "Analisis Dan Perancangan Knowledge Management System Pada Sma Negeri 6 Kota Jambi," vol. 2, no. 3, 2017.

[2] E. Retnoningsih, P. Studi, M. Informatika, and I. Pendahuluan, "Analisapenerapan Knowledge Management System Perguruan Tinggi Menggunakan MOST," vol. II, no. 2, pp. 1-10, 2014.

[3] H. A. N. Sulaiman, "Knowledge Management System Service Center Berbasis Web," vol. 8, no. 3, pp. 220-230, 2015.

[4] J. Manajemen, F. Ekonomi, U. B. Nusantara, J. K. H. S. No, and J. Barat, "Knowledge Management Di Perguruan Tinggi Harjanto Prabowo," no. 9, pp. 407-415.

[5] I. Yuniva, "Perancangan Model Knowledge Management System Berbasis Web," vol. XVIII, no. 1, pp. 38-47, 2016.

[6] D. Driyani, "Prototipe Materi Ajar Sma Berbasis Knowledge Management System Dengan Software Development ' CMS Lokomedia ,"' vol. 7, no. 3, pp. 236247, 2014.

[7] T. Afrizal and H. Sulaiman, "Bimbingan Belajar Bunglon Group," pp. 113-118, 2018.

[8] W. Usino and R. U. Hadi, "Knowledge Management System berbasis Web Dengan Pendekatan SECI pada Kantor Cabang Dinas Pendidikan dan Kebudayaan Kabupaten Pandeglang," pp. 699-703, 2018.

[9] S. Kasus, S. Menengah, and K. Negeri, "Berbasis Web," 2013.

[10] B. A. B. Ii and L. Teori, "Prototype . Prototype Model," pp. $1-26$. 